\title{
THE MEANING OF THE VERB “TO SOUND" IN MUNA LANGUAGE: NATURAL SEMANTIC METALANGUAGE
}

\author{
La Aso $^{1} \quad$ Maulid Taembo ${ }^{2}$ \\ Universitas Halu Oleo \\ la_aso@yahoo.co.id ${ }^{1} \quad$ Maulid.taembo@rocketmail.com²
}

$\begin{array}{lll}\text { Received: } 09-10-2017 & \text { Revised: } 15-10-2017 & \text { Accepted: 26-10-2017 }\end{array}$

How to Cite: Aso, L. (2017) The Application of Pictures and Peer Assessment for teaching Descriptive Text in Writing Class. RETORIKA: Jurnal Ilmu Bahasa 3(2). 265-270

DOI: $10.22225 / \mathrm{jr} \cdot 3.2 .336 .265-270$

\begin{abstract}
This paper aims at investigating the variations of lexicon having meaning of "produce of sound" in Muna language based on natural semantics metalanguage. The data collecting was done by participant speaking and scrutinize methods through interview and noting techniques. It was analyzed by using natural semantics metalanguage (NSM), an approach to investigate various lexicons with principle "one form for one meaning and one meaning for one form". Based on the result of this study founded that meaning of "produce of sound" of Muna can be expressed by a number of lexicons and each form has distinctive meaning like in the lexicons of kobheghu, kobhondu, kotighi, kopisi, korasa, korangku, kondii, konduu, kopere, kombote, kopaka, koradha, kobuu, korapa, and kohuhu. All lexicons of Muna language has meaning 'produce of sound'. The use of each lexicon depends on the sounded object/tool, object/tool that create the sound, and the way of creating the sound.
\end{abstract}

Keywords: produce of sound, natural semantics metalanguage, distinctive

\section{INTRODUCTION}

Muna language is one of the regional languages spoken by Muna ethnic in Muna Regency of Southeast Sulawesi Province. This language has some uniqueness, especially when it is used to give names or terms for certain events. Therefore, the language of Muna includes regional languages that are rich of lexical elements. One of the uniqueness of this language is to provide some naming for the meaning of the verb 'to sound'. The meaning of the verb 'to sound' in Muna language can be realized with many lexicons. In other words, every lexicon has a distinctive meaning.

One of tools for describing lexicons with distinguishable meanings is through the use of natural semantic metalanguage method. Through this method, the meaning of the verb 'to sound' in Muna language can be explained more fully and in detail. As it is known that every lexicon element has certain characteristics, with its various semantic features. The semantic characteristics can be extracted through natural semantic metalanguage method. Thus, the meaning of the verb 'to sound' with its various elements in the Muna language can be known more clearly and completely as the meaning has been given by the Muna community since ancient times. This article will analyze every variation of the lexicon in the Muna language which means 'to sound'.

Meanwhile, the theory used in this research is the theory of NSM (Natural Semantic Metalanguage). NSM was pioneered by Wierzbicka, a Polish semantic scholar since 1972, and later developed by Cliff Goddard. Goddard (1994: 2) mentions that the meaning analysis in NSM theory will be complete and the meaning of any complex can be explained clearly. This theory is considered very precise because NSM can express all the meanings of lexical, illocution, and grammatical meaning revealed from metalanguage and derived from basic or natural language.

The basic principle of NSM is a form for one meaning and one meaning for one form. This means that one meaning can be realized in one form, or one form containing only one original meaning. Another principle of NSM is that it provides a reduction of lexical meaning with simple paraphrasing in a systematic frame of expression (Wierzbicka, 1996; Goddard 1998: 29). Both of these principles with the support of the concept of NSM is able to describe and analyze the various meanings thoroughly.

Sudipa (2006: 2) adds that the natural condition of a language can retain one form for one meaning and one meaning for one form. In addition, Sudipa (2012: 50) states that natural semantic metalanguage arranged to reveal all the 
meaning of both lexical meaning, illocution, and grammatical meanings. The very basic thing in this theory is that the meaning given must be the original meaning, as the meaning inherited from human from birth. Therefore, this theory begins with the investigation of the original meaning empirically. The original meaning is a set of meanings that cannot change despite cultural changes, and has been inherited from birth.

Furthermore, NSM has several concepts, namely the original meaning / primitive, illocution, non-compositional polysemy, general syntax, valence selection, and resonance. However, this simple study only uses three concepts, namely the original meaning / primitive, polysemy non-composition, and the general syntax. This is based on the view expressed by Lehrer (1992); Koch (2001); and Koptjevskaja-Tamm (2008) associated with three basic concepts of meaning. The original meaning is a fixed meaning that humans inherit from birth. Noncompositional polysemy are two original meanings that have no composition relationships because each has a different grammatical relationship. General syntax is a combination of elements or grain original meaning lexicon appears universally expected. In addition, to clarify the meaning of certain words, the important thing to know is the original meaning of the word with the support of paraphrase usage in defining the meaning of the word.

Based on the above description of the theory, this study uses two NSM principles with NSM concept support as mentioned above to describe and analyze the meaning of the verb 'to sound' in Muna language. This indicates that NSM can explain difficult meanings in a simple way, including all the lexicon variations meaning 'sound' in Muna language as being described below.

\section{METHOD}

The provision of data is done by using conversation and observation method (Sudaryanto, 1993:131). The conversation method is done by personal conversation technique, which is to go to every research location and have conversation sourced from inducement in the form of questionnaire. The observation method is done by tapping technique followed by advanced techniques in the form of note-taking and recording technique. Tapping technique means researchers intercept the use of informant lan- guage. Furthermore, the technique of notetaking, which is to record about the list of questions and matters relating to the object studied and simultaneously record the use of informant language using tape recorder. In addition, the translation method of the data is also done, i.e. Muna language data is translated into English. The collected data were analyzed using the theory of natural semantic metalanguage (NSM) using three NSM concepts, original meaning / primitive meaning, non-compositional polysemy, and universal syntax.

\section{RESULT AND DISCUSSION}

Based on the data found in the field, the meaning of the verb 'to sound' in Muna language can be realized with several lexicons and each lexicon has a distinctive meaning. Muna languages include regional languages whose sentence form always uses the pronoun prefix attached to the verb as the subject marker. Therefore, to make it easier to understand the sentence form in Muna language it is worth mentioning that the pronoun prefix is always embedded in the Muna language verb. However, the pronoun prefix found in the sample is only one, i.e. the prefix / no / which serves as the third single subject marker.

ased on the results of data analysis, lexicons related to the meaning of the verb 'to sound' in Muna language vary greatly depending on the object / device that sounds, how to sound (the type / sound model), and the tool / object that causes the object / device to sound. These lexicons can be seen in the following description. In the given sentence examples, it uses the abbreviation BM for the Muna language and $\mathrm{BI}$ for the sentences of Indonesian language.

\section{Kobeghu 'to sound'}

Kobheghu means 'to sound' which is only used when an object is thrown into the water / river / sea / well. The sound of objects thrown into the water is called kobeghu in Muna language.

The examples in the sentences:

\section{BM : Bhakeno ghai mondawuno welo laa no- kobheghu. \\ BI : The coconut that fell in that time sounded}

BM : O kenta no-punda welo tehi nokobheghu 
BI : The fish that jumped into the sea sounded

Based on the above example it can be seen that lexicon kobeghu is only used in the meaning of sound associated with the sound of air and not on the other.

\section{Kobhondu 'to sound'}

Kobhondu means 'to sound', used when the fruit falls from the tree and is still intact (not broken / destroyed). The sound of fallen fruit is called kobhondu in Muna language.

The examples in the sentences:

BM : Bhakeno foo mondawuno morondo nokobhondu

BI : Mango fruit that fell last night sounded

BM : Ghai kaghio mondawuno maighoono ne laano no-kobhondu

BI : The dry coconut fruit that fell from the tree sounded

Based on the above example it can be seen that lexicon kobhondu is only used in the meaning of sounds associated with the sound of fallen fruit and not broken. In that sense, if the fruit is broken, then it is not called kobhondu.

\section{Kotighi 'to sound'}

Kotighi means 'to sound', it is used when crashing iron into another iron or hard rocks striking against other hard rocks. The sound of iron / stone is called kotighi in Muna language.

For examples:

BM : A-tangkisi ane ghuti kapuluno sampe no -kotighi

BI : I turned the machete with iron until it sounded

BM : Ae-bhoghari kontu no-kotighi

BI : I broke the stone it sounded

Based on the above examples it can be seen that lexicon kottyi is only used in the meaning of sounds associated with sounds of iron objects and rocks and is not used in any other way.

\section{Kopisi 'to sound'}

Kopisi means 'to sound', used when we hit (slap) one part of someone's body parts. The sound of limbs that is hit is called kopisi in $\mathrm{Mu}-$ na language.

For examples:

BM : A-bhampisi bhagano sampe no-kopisi
BI : I slapped her cheek until it sounded

BM : Amaku no-tofa wampaniku sampe nokopisi

BI : My father slapped my shoulder until it sounded

Based on the above example it can be seen that the lexicon kopisi is only used in the meaning of sounds associated with the sound of limbs that is hit by hand.

\section{Korasa 'to sound'}

Korasa means 'to sound', used when we step on dry leaves. The sound of leaves that are trampled is called korasa in Muna language.

For examples:

BM : A-finda ne roono kamateno kuidawa nokorasa

BI : I stepped on the dried teak leaves it sounded

BM : O manu no-tende te wo roono kamateno sau no-korasa

BI : Chickens ran on the leaves of dried trees it sounded

Based on the above examples it can be seen that the lexicon korasa is used only in the meaning of the sound associated with the sound of the leaves that are crushed, and it is not used on other objects.

\section{Korangku 'to sound'}

Korangku means 'to sound' that is used in the kitchen tools (such as plates, cups, spoons, cooking pot, frying pan, etc.) when it stores in baskets or in sacks that are touching. The sounds of objects that occur as a result of touching each other are called korangku in Muna language.

For examples:

\section{BM : Ihino kalangkano no-korangku rampa-} no bhe pirihino bhe sendono we lalo.

BI : The contents of the basket sound because in it there are several plates and spoons

BM : Kadu katongkuno no-rangku rampahano bhe pantihino we lalo

BI : The sack that he is carrying sounds because in it are several pots

Based on the above examples can be seen that the lexicon korangku is used only in the meaning of the sound associated with kitchen 
tools, specifically from the glass objects, iron, or pot (not plastic as well as timber).

\section{Kondii 'to sound'}

Kondii means 'to sound' when a gong is hit or a flute is blown. The sound of the gong or flute is called kondii in Muna language.

For examples:

BM : Ane dorambie mbololo no-kondii

BI : Gong will sound when struck

BM : La Ege ne-punto suli no-kondii

BI : La Ege blew the flute it sounded

Based on the above examples it can be seen that the lexicon kondii is often used in the meaning of sound associated with the instrumental music or the purpose found in musical instruments.

\section{Konduu 'to sound'}

Konduu means 'to sound' that is used when we shoot with a gun. The sounds coming out of gunshot is called konduu in Muna language.

For examples:

BM : Sinapano no-kunduu wakutuno netemba manu-manu

BI : His gun sounded when he shot a bird

BM : Tantara atatu no-konduu pisitolono hadae ne-temba ndoke

BI : The soldier's pistol sounded, maybe he shot an ape.

Based on the above examples it can be seen that the lexicon konduu is used in the meaning of the sound associated with the sound coming out of the gun when it is removing the bullet.

\section{Kopere 'to sound'}

Kopere means 'to sound', used when we tear the cloth by hand. The sound of the torn cloth is called kopere in Muna language.

For examples:

\section{BM : Inaku no-wia bheta katampolino no-} kopere

BI : My mother tore the sheath that she sewed it sounded

BM : Isaku nohela bhajuku no-kepere sampe no-wia

BI : My sister pulled my shirt till torn it sounded
Based on the above examples it can be seen that the lexicon kopere is generally used in the meaning of the sound associated with the sound of torn cloth.

\section{Kombote 'to sound'}

Kombote means 'to sound', used when the fingers or toes are pulled. The sound of the finger / toe joint is called a kombote in Muna language.

BM : Inaku no-bunati wunano limano sampe no-kombote.

BI : My mother pulled her fingers until it sounded

BM : Fokoamauku no-sepa kanau sampe nokombote wunano ghagheno

BI : My uncle kicked me at last his toes sounded

Based on the above examples it can be seen that the lexicon kombote is generally used in the meaning of the sound associated with the sound of the finger joints.

\section{Kopaka 'to sound'}

Kopaka means 'to sound', used when the corn is picked from a tree or a branch of wood that sounds before it is broken. The sound of corn when picked or the sound of a branch of wood / branch of a cracked that will be broken is called kopaka in Muna language.

For examples:

\section{$B M$ : O ndoke ne-tongka bhakeno kahitela sampe no-kopaka}

BI : The monkey picked the corn until it sounded

BM : Raghano kulidawa atatu no-kopaka rampano no-busoe kawea moghosano

BI : The teak branch sounded because it is blown by the strong wind.

Based on the above examples it can be seen that the lexicon kopaka is not used to the sound of a twig / branch wood that has been broken, as a result of a direct cut and broken.

\section{Koradha 'to sound'}

Koradha means 'to sound', used when wood is slammed by a large wooden fellow. The sound of the slammed wood is called koradha in Muna language.

For examples:

BM : Amaku no-fohala sau katongkuno 
sampe no-koradha

BI : My father dropped the wood that he was carrying until it sounded

BM : O wewi ne-sambara katondo sampe nosansa bhe no-koradha

BI : The pig crashed into the fence until it fell apart and sounded

Based on the above examples it can be seen that the lexicon koradha is not used to the sound of people / animals who slammed, but generally occurs in the wood smashed (intentionally or accidentally).

\section{Kobuu 'to sound'}

Kobuu means 'to sound', used for a loud fart. The sound of the fart is called kobuu in Muna language.

For examples:

BM : Mie moleno taghi atatu ne-ghotu nokobuu

BI : The man with the stomachache farted and it sounded

BM : Kamokula atatu ne-ghotu no-kobuu

BI : The old man farted and it sounded

Based on the above examples it can be seen that the lexicon kobuu is used only in the meaning of the sound associated with the fart in loud sounds.

\section{Korapa 'to sound'}

Korapa means 'to sound', used for birds or chickens that move both wings when it is slaughtered or fighting. The sound of chicken / bird wings is called korapa in Muna language.

For examples:

\section{BM : Manu ni-sumbele pada no-korapa maka} no-mate

BI : Chickens slaughtered before its death both wings sounded

BM : Manu-manu atatu no-korapa panindo rampano do-posawu

BI : The wings of the bird sound because they are fighting

Based on the above examples it can be seen that the lexicon korapa is used only in the meaning of the sound associated with the sound of the wings of animals that generally occur accidentally or involuntarily.

\section{Kohuhu 'to sound'}

Kohuhu meaning 'to sound' is used for the sound of a vehicle using a machine. The sound that comes out of the vehicle is called kohulu in Muna language.

For examples:

BM : Motoroku no-kohuhu a-gasie.

BI : My bike sounds when I hold the gas grip

BM : Oto ngkodau atatu mina no-kohuhu masinano

BI : The engine of the old car does not sound

Based on the above examples it can be seen that the lexicon kohuhu is used only in the meaning of the sound associated with the sound of vehicle engines.

\section{CONCLUSION}

Based on the above results and discussion it can be seen that the meaning of 'to sound' in Muna language can be realized with various forms of lexicon. Each form of the lexicon has a distinctive meaning, which distinguishes it from other lexicons. The lexicons associated with the meaning of 'to sound' in Muna language can be divided into several types. In this article it is described 15 types of lexicon, namely kobheghu, kobhondu, kotighi, kopisi, korasa, koruku, kondiu, konduu, kopere, kombote, kopaka, koradha, kobuu, korapa, and kohuhu. All of Muna's lexicon have the meaning of 'to sound'. The use of each lexicon depends on the device / thing that sounds, the instrument / object that causes it to sound, and how to sound it.

These findings reinforce that through the natural semantic metalanguage, all meanings can be clearly and completely described. Through natural semantic metabahasa, someone can use the right word to describe something without using another lexical or without convoluting.

\section{ACKNOWLEDGEMENT}

the authors would like to thank the reviewers for their input feedback for the improvement of this article.

\section{DAFTAR PUSTAKA}

Goddard, Cliff. 1998. Semantic analysis. Oxford: Oxford University Press. [2nd ed'n in press].

Koch, Peter. 2001. Lexical typology from a cognitive and linguistic point of view. In Martin Haspelmath, Ekkehard König \& Bernard 
Comrie (eds.), Language typology and language universals, Vol 2, 1142-1178. Berlin: Walter de Gruyter.

Koptjevskaja-Tamm, Maria. 2008. Approaching lexical typology. In Martine Vanhove (ed.), From polysemy to semantic change: A typology of lexical semantic associations, 3-54. Amsterdam: John Benjamins.

Lehrer, Adrienne. 1992. A theory of vocabulary structure: Retrospectives and prospectives. In Martin Pütz (ed.), Thirty years of linguistic evolution, 243-256. Amsterdam: John Benjamins.

Sudaryanto. 1993. Metode dan Aneka Teknik Ana- lisis Bahasa Pengantar Penelitian Wahana Kebudayaan Secara Linguistik. Yogyakarta: DutaWacana University Press.

Sudipa, I Nengah. 2006. "Verba Tindak Tutur Bahasa Bali: Suatu Kajian ahasa" dalam Kongres Bahasa Bali VI, 2006. Denpasar: Universitas Udayana.

Sudipa, I Nengah. 2012. "Makna Membawa Bahasa Bali: Pendekatan Metabahasa Semantik Alami". Jurnal of Bali Studies, Volume 02,Nomor 02, Oktober 2012: Denpasar.

Wierzbicka, A. 1996b. Semantics: Primes and Universals. Oxford: Oxford University Press. 